DOI: https://doi.org/10.18371/fp.3(43).2021.859610

УДК 657.37:336.73

\title{
РОЗВИТОК ПРОГРАМНОГО ЗАБЕЗПЕЧЕННЯ ЯК ТЕХНІЧНОЇ СКЛАДОВОЇ ОРГАНІЗАЦІЇ БУХГАЛТЕРСЬКОГО ОБЛІКУ В ЛОМБАРДАХ
}

\section{ГОНЧАРЕНКО Олена Олексї̈вна}

к.е.н., доиент, дочент кафедри фінансів і обліку

Черкаського навчально-наукового інституту

Університету банківської справи

ORCID ID: https://orcid.org/0000-0001-9479-9797

\section{ШИНКАРЕНКО Ольга Миколаївна}

к.е.н., доиент,

дочент кафедри фінансів і обліку

Черкаського навчально-наукового інституту

Університету банківської справи

ORCID ID: https://orcid.org/0000-0002-7621-7017

Анотація. B статті деталізовані вимоги до програмного забезпечення ломбардів, щчо повинні корелювати як з нормативним вимогам, так $i$ забезпечувати інформаційні потреби внутрішніх користувачів. Відповідно до визначених вимог, надано очінку сучасним програмним продуктам і сервісам, призначеним для ведення бухгалтерського обліку діяльності ломбардів, та відзначено їх «неповночінність» в реалізації процесу звітування. Виокремлено системи забезпечення подання електронної звітності та обміну електронними документами, які можуть бути інтегровані з існуючими програмними продуктами і сервісами ломбардів. Обтрунтовано та деталізовано критерії оптимального вибору програмного забезпечення ломбардів, конкретизачія яких повинна здійснюватися кожною установою самостійно та враховувати реципрокність технічних пристроїв та програмного забезпечень.

Ключові слова: ломбарди, організачія бухгалтерського обліку, програмне забезпечення, програмні продукти і сервіси.
Аннотация. $B$ cmaтье детализированные требования $\kappa$ программному обеспечению ломбардов, которые долюны коррелировать как с нормативными требованиями, так и обеспечивать информачионные потребности внутренних пользователей. В соответствии с определенными требованиями, дана оценка программным продуктам и сервисам, предназначенным для ведения бухгалтерского учета деятельности ломбардов, и отмечено их «неполноченности» в реализачии прочесса формирования и подачи отчетности. Выделены системы обеспечения подачи электронной отчетности и обмена электронными документами, которые могут быть интегрированы с существуюшими программными продуктами и сервисами ломбардов. Обосновано и детализировано критерии оптимального выбора программного обеспечения ломбардов, конкретизация которых долюнна осуществляться каждым учреждением самостоятельно и учитывать взаимообусловленность технических устройств и программного обеспечения. 
Ключевые слова: ломбарды, организация бухгалтерского учета, программное обеспе-

Постановка проблеми. В практичній діяльності ломбардів система бухгалтерського обліку функціонує в тісному взаємозв'язку з системою менеджменту, у зв'язку з чим відбуваються взаємні проникнення об'єктів їх регулювання, що спричинює необхідність врахування теоретичних положень менеджменту 3 метою пошуку оптимальної моделі організації бухгалтерського обліку ломбардів.

Специфіка діяльності ломбардів як небанківських фінансових установ при організації бухгалтерського обліку зумовлює необхідність враховувати законодавчі вимоги, вимоги регулятора i потреби управлінського персоналу. Виокремлюючи в організації бухгалтерського обліку ломбардів ряд компонентів, як то методика, обліковий персонал, техніка і технологія, наголошуємо на особливій актуальності саме технічної складової бухгалтерського обліку, до якої будемо відносини технічні пристрої (комп'ютерна техніка, засоби зв'язку, мережеві пристрої) і програмне забезпечення.

Аналіз останніх досліджень і публікацій. Питання вибору бухгалтерського програмного забезпечення піднімали у своїх працях С. Івахненков [1], О. Павелчак-Данилюк [2], I. Чернікова [3], І. Гриб-чук і Г. Ляхович [4], В. Одноволик [5], О.Гончаренко і О. Лук'янець [6], К. Вольська і А. Дикий [7] та інші.

Діяльність ломбардів $є$ нормативно зарегламентованою, тобто, окрім законодавчих актів, вимоги щодо окремих аспектів провадження діяльності зазначених установ конкретизуються в розпорядчих документах Національної комісії, що здійснює регулювання ри- чение, программные продукты и сервисы.

нку фінансових послуг ${ }^{1}$, та Національного банку України. I саме такими документами визначаються вимоги до технічного і програмного забезпечення ломбардів.

Необхідність дотримання зазначених вимог для ломбардів встановлюється ще до початку надання фінансових послуг, і підтверджується документами (довідками) про наявність і відповідність вимогам технічного і програмного забезпечення, що подаються установами до Державного реєстру фінансових установ для набуття статусу фінансової установи та отримання ліцензії на провадження діяльності 3 надання фінансових послуг [8, 9].

Відповідно, ще на етапі планування техніки, як компоненту організації бухгалтерського обліку, необхідним $\epsilon$ виконання завдання вибору технічного і програмного забезпечення, що буде відповідати нормативним вимогам, вимогам користувачів (облікових працівників, управлінського персоналу тощо) та забезпечувати реалізацію технології в процесі досягнення мети бухгалтерського обліку.

Мета статті полягає в комплексному дослідженні вітчизняного ринку програмних продуктів, призначених для ведення бухгалтерського обліку діяльності ломбардів, визначенні груп вимог та виокремленні критеріїв вибору оптимального бухгалтерського програмного забезпечення ломбардів.

\footnotetext{
1 Державне регулювання і нагляд у сфері ринків фінансових послуг з 01 липня 2020 здійснює Національний банк Україні, проте, щодо небанківських фінансових установ діють розпорядчі документи Національної комісії, що здійснює регулювання ринку фінансових послуг, до визнання відповідних актів такими, що втратили чинність в установленому порядку [22]
} 
Виклад основних результатів дослідження. Положенням про Державний реєстр фінансових установ та Положенням про визначення умов провадження діяльності з надання фінансових послуг, здійснення яких потребує відповідної ліцензії (ліцензійних умов) вимоги до програмного забезпечення та спеціального технічного обладнання представлені як вимоги до облікової та реєструючої систем, хоча ні самих вимог, ні визначень цих понять зазначені нормативні документи не містять. Більш-менш конкретні вимоги передбачені для комп'ютерної техніки і засобів зв'язку: комп'ютерна техніка повинна забезпечувати «ведення обліку та реєстрацію операцій 3 надання фінансових послуг та виконання вимог щодо подання до Національного банку інформації», а засоби зв'язку повинні включати телефон, Інтернет, електронну пошту $[8,9]$.

Якщо попередні вимоги стосуються всіх небанківських фінансових установ (кредитні спілки, ломбарди, фінансові компанії), то для ломбардів передбачені деталізовані вимоги до технічного і програмного забезпечення:

1. технічне забезпечення:

- повинно створюватись на основі комп'ютерних систем;

- має забезпечувати виконання технологічних операцій з ведення обліку;

2. програмне забезпечення:

- захист від несанкціонованого доступу;

- забезпечує синтетичний, аналітичний, в т.ч. натуральний облік, а також формування звітності;
- експорт інформації (звітних даних) у форматі, визначеному Національним банком України [10].

Зважаючи на нормативні вимоги, оновлення складу і розширення функціонального призначення програмних продуктів відбувається постійно і на сьогодні ринок комп'ютерних систем бухгалтерського обліку пропонує:

- традиційні бухгалтерські програми (локальна, мережева або «клієнт-серверна» версія);

- програмні сервіси для ведення обліку на основі хмарних технологій;

- системи забезпечення подання електронної звітності та обміну електронними документами (термінальні та online).

Вітчизняний ринок програмних продуктів, призначених для ведення бухгалтерського обліку діяльності ломбардів представлений наступними бухгалтерськими програмами: «Lombard gold», «Pawn Shop», «Pawn Expert», «Все в одному: CUProgram», «ISpro». В той же час, програмні продукти «Pawn Shop» i «Pawn Expert» не $€$ комплексними програмними рішеннями, а призначені для автоматизації роботи (в тому числі і облікової) frontофісів щодо операційної діяльності, а для обліку загальнокорпоративних об'єктів (основних засобів, нематеріальних активів, запасів, заробітної плати тощо) передбачена їх інтеграція 3 «1C:Підприємство. Бухгалтерія для України» шляхом завантаження агрегованих даних 3 «Pawn Shop» або «Pawn Expert», що зумовлює неможливість отримання аналітичної інформації за різними об'єктами обліку в одній програмі, спричинює витрати на придбання та підтримку двох програмних продуктів, «ручні» операції вивантаження i завантаження даних $€$ 
ризиковими щодо коректності та технічної сумісності у випадках оновлення програм.

Програмний продукт «Lombard gold» $є$ галузевою конфігурацією, яка працює на платформі «1С:Підприємство. Бухгалтерія для України», що обумовлює необхідність здійснення витрат як на платформу, так і на відповідну конфігурацію. При цьому, програмне забезпечення «Lombard gold» має дві конфігурації під версії 7.7 i 8.3 платформи «1С:Підприємство», що суттєво відрізняються в ціні.

Універсальність і незалежність програмного забезпечення «Все в одному: CUProgram» i «ISpro» $є$ як їх перевагою, так і недоліком, оскільки ломбарди мають свої специфічні характеристики операцій господарської діяльності, які зумовлюють необхідність додаткових налаштувань i, відповідно, додаткових витрат. Так, базова версія «Bce в одному: CUProgram» найкраще підходить для кредитних спілок, але певні доопрацювання програмного продукту дозволять використовувати його й ломбардам. «ISpro» $є$ модульною програмою, тобто іiі функціонал залежить від кількості придбаних мо- дулів (бухгалтерський i податковий облік, ведення договорів, відносини 3 клієнтами, управління персоналом, розрахунки з контрагентами тощо), які потребують налаштувань під конкретний вид діяльності і специфіку установи. В той же час, «ISpro» відзначається швидкістю і надійністю роботи 3 великими масивами даних і значною кількістю робочих місць (понад 100), в тому числі і віддалених.

Програмні сервіси для ведення обліку на основі хмарних технологій представлені на ринку з типом хмари SaaS (Software as a service - програмне забезпечення як послуга). Проте, наявні на сьогодні бухгалтерські хмарні сервіси не пропонують конфігурацій для ломбардів, що унеможливлює їх використання як повноцінного програмного забезпечення. Проте, такі хмарні продукти як «Бухгалтерія Онлайн» (Приватбанк) і «1C: Підприємство» (Актив-Софт, Cloudhub Online24, Victoria IT Lab) забезпечують можливість інтеграції даних 3 «Pawn Shop» i «Pawn Expert», аналогічно 3 традиційною програмою «1C: Підприємство» (локальна, мережева, клієнт-серверна версіі) (табл. 1).

Таблиця 1

Бухгалтерські хмарні сервіси в Україні

\begin{tabular}{|l|l|c|}
\hline \multicolumn{1}{|c|}{ Назва продукту/ провайдер } & \multicolumn{1}{|c|}{ Інтернет-джерело } & \multicolumn{1}{c|}{ Інтеграція } \\
\hline «Бухгалтерія Онлайн» / Приватбанк & https://bo.pb.ua/ & «Pawn Shop», «Pawn Expert» \\
\hline Облік Sаas & https://ioblik.com/ & - \\
\hline «1C: Підприємство» / Актив-Софт & $\begin{array}{l}\text { https://aktiv.ua/1c-online/about- } \\
\text { 1c-online }\end{array}$ & «Pawn Shop», «Pawn Expert» \\
\hline $\begin{array}{l}\text { «1C: Підприємство» / Cloudhub } \\
\text { Online24 }\end{array}$ & $\begin{array}{l}\text { http://online24.net.ua/products/ } \\
\text { 1c-ukr.html }\end{array}$ & «Pawn Shop», «Pawn Expert» \\
\hline «1C: Підприємство» / Victoria IT Lab & $\begin{array}{l}\text { https://saas-vic.com/zamoviti- } \\
\text { orendu-1s-v-hmari/ }\end{array}$ & «Pawn Shop», «Pawn Expert» \\
\hline Bookkeaper & https://bookkeeper.kiev.ua/ & \multicolumn{1}{|c|}{} \\
\hline
\end{tabular}

Джерело: власна розробка авторів

Ломбарди потенційно можуть ти на цей вид технологій у зв'язку 3 використовувати бухгалтерські хмарні сервіси, але не поспішають переходиризиками втрати даних, гальмування роботи всієї установи, перебоїв в Інте- 
рнет-мережі, хакерських атак тощо, а також релевантністю витрат на сервіс.

Отже, під час вибору програмного забезпечення для ведення обліку в ломбардах варто враховувати його відповідність як нормативним, так і користувацьким вимогам (табл. 2).

На вибір програмного забезпечення також впливає здатність останнього автоматично формувати регламенто- вану звітність в електронному вигляді та передавати іiі контролюючим органам (Національному банку України, Державній фіскальній службі, Державній службі статистики України тощо) 3 накладанням кваліфікованих електронних підписів, а також здатність здійснювати обмін електронними документами 3 контрагентами.

Таблиця 2

Оцінка програмного забезпечення для ведення бухгалтерського обліку в ломбардах

\begin{tabular}{|c|c|c|c|c|c|c|c|}
\hline \multirow[b]{2}{*}{ № } & \multirow[b]{2}{*}{ Критерії } & \multicolumn{6}{|c|}{ Програмне забезпечення } \\
\hline & & 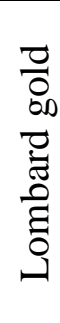 & $\begin{array}{c}\frac{2}{8} \\
\frac{\pi}{n} \\
\frac{1}{\sigma} \\
0\end{array}$ & 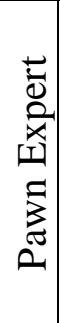 & 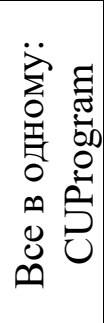 & $\frac{0}{\tilde{2}}$ & 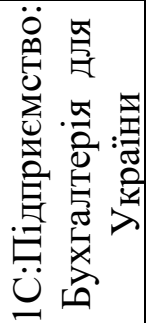 \\
\hline \multicolumn{8}{|c|}{ Нормативні } \\
\hline 1. & резервне копіювання та відновлення даних & + & + & + & + & + & + \\
\hline 2. & розмежування та обмеження прав доступу до даних & + & + & + & + & + & + \\
\hline 3. & конфіденційність (використання паролів) & + & + & + & + & + & + \\
\hline 4. & наявність інформаційно-довідкової системи & + & - & - & + & + & + \\
\hline 5. & $\begin{array}{l}\text { можливість відстеження інформації про порушення планових } \\
\text { платежів за кредитними договорами }\end{array}$ & + & + & + & + & + & + \\
\hline 6. & розрахунок фінансових нормативів діяльності & - & - & - & + & - & + \\
\hline 7. & формування регламентованої звітності & + & - & - & + & + & + \\
\hline 8. & формування спеціальної звітності (звітних даних) & + & - & - & + & - & - \\
\hline 9. & $\begin{array}{l}\text { відповідність форматів файлів електронної форми звітних } \\
\text { даних формату, установленому Національним банком Украї- } \\
\text { ни }\end{array}$ & - & - & - & - & - & - \\
\hline 10. & підтримка багатопоточності & + & + & + & + & + & + \\
\hline 11. & $\begin{array}{l}\text { зберігання аудит-інформації про автора та час створення, } \\
\text { модифікації та видалення будь-якої інформації у системі }\end{array}$ & + & + & + & + & + & + \\
\hline 12. & можливість архівування і відновлення архіву & + & + & + & + & + & + \\
\hline \multicolumn{8}{|c|}{ Користувацькі } \\
\hline 13. & інтеграція з іншими інформаційними системами & + & + & + & + & + & + \\
\hline 14. & $\begin{array}{l}\text { ведення обліку за центрами відповідальності (відокремлени- } \\
\text { ми підрозділами) }\end{array}$ & + & + & + & + & $-*$ & + \\
\hline 15. & введення господарських операцій вручну & + & + & + & + & + & + \\
\hline 16. & оновлення регламентованих форм документів, звітності & + & + & + & + & + & + \\
\hline 17. & формування нерегламентованої (управлінської) звітності & + & & - & - & + & $-*$ \\
\hline 18. & ведення обліку загальнокорпоративних об’єктів & + & & - & - & + & + \\
\hline 19. & ведення обліку специфічних об’єктів & + & & + & + & + & $-*$ \\
\hline 20. & ведення складського обліку & + & & + & + & + & + \\
\hline
\end{tabular}


Закінчення табл. 2

\begin{tabular}{|c|c|c|c|c|c|c|}
\hline 21. & ведення податкових розрахунків & + & - & - & + & + \\
\hline 22. & підтримка формату iXBRL & - & - & - & - & - \\
\hline 23. & інтуїтивно-зрозумілий інтерфейс & + & $\begin{array}{c}+1 \\
-\end{array}$ & $+/-$ & $\begin{array}{c}+1 \\
-\end{array}$ & + \\
\hline \multicolumn{7}{|c|}{ Інші } \\
\hline 24. & варіант постачання: & & & & & \\
\hline 25. & локальна версія програми & + & + & + & + & + \\
\hline 26. & мережева версія програми & + & + & + & + & - \\
\hline 27. & «клієнт-серверна» версія програми & + & - & - & + & + \\
\hline 28. & хмарні технології & - & - & - & - & - \\
\hline 29. & $\begin{array}{l}\text { необхідність придбання додаткового програмного забезпе- } \\
\text { чення }\end{array}$ & + & + & + & - & - \\
\hline
\end{tabular}

* можливість реалізації вимог за додаткову плату шляхом індивідуального замовлення щодо доопрацювання програмного модуля та придбання додаткових модулів

Джерело: складено на основі опрацювання $[11,12,13,14,15]$

Нажаль, наявне програмне забезпечення для ведення бухгалтерського обліку в ломбардах не здатне самостійно виконати таке завдання. Проте, існують системи забезпечення подання електронної звітності та обміну електронними документами, які можуть бути застосовані одночасно зі спеціалізованим програмним забезпеченням ломбардів або ж інтегровані 3 ними.

Ринок такого програмного забезпечення (термінального) та/або сервісів (online) представлений досить широко: M.E.DOC, Соната, Арт-Звіт, 1C:Звіт, FreeZvit, Sota, iFin, Taxer. Найбільш інтегрованими $є$ облікові програмні продукти, що побудовані на платформі 1C:Підприємство: «Lombard gold» i «ISpro», для інших або необхідна «програма-посередник»

«1С:Підприємство. Бухгалтерія для України» («Pawn Shop», «Pawn Expert»), або звужується вибір інтегрованої системи до використання тільки програми M.E.DOC, Bce в одному: CUProgram (табл. 3).

Окрім регламентованої звітності, ломбарди зобов'язані подавати регулятору звітні дані в електронній формі у вигляді файлів 3 показникам звітності відповідно до Реєстру показників звітності учасників ринку небанківських фінансових послуг, розміщеного на сторінці офіційного Інтернетпредставництва Національного банку України в розділі «Статистика/Організація статистичної звітності/Реєстр показників звітності учасників ринку небанківських фінансових послуг», у форматі XML через вебпортал Національного банку (https://portal.bank.gov.ua).

Наразі декілька систем забезпечення подання електронної звітності надають можливість формувати та подавати звітні дані встановленого формату регулятору: M.E.Doc (модуль «Звітність до НБУ для небанківських фінустанов»), Арт-Звіт (Тип звіту НБУ), FREDO (Звітність до НБУ) [16, 20, 21].

Висновки. Програмне забезпечення для ведення бухгалтерського обліку в ломбардах, системи забезпечення подання електронної звітності та обміну електронними документами мають відповідати ряду критеріїв, які доречно об'єднати в чотири групи: 
Таблиця 3

Системи забезпечення подання електронної звітності та обміну електронними документами

\begin{tabular}{|c|c|c|c|c|c|c|c|c|}
\hline \multirow[b]{2}{*}{ Критерії } & \multicolumn{8}{|c|}{$\begin{array}{c}\text { Системи забезпечення подання електронної звітно- } \\
\text { сті }\end{array}$} \\
\hline & 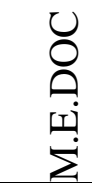 & ث̊ & 国 & 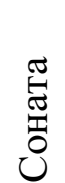 & 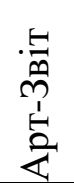 & 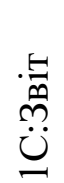 & 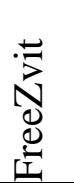 & 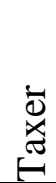 \\
\hline \multicolumn{9}{|l|}{ варіант постачання } \\
\hline термінал & + & - & $-/+$ & + & + & + & + & - \\
\hline online & - & + & + & - & + & - & - & + \\
\hline $\begin{array}{l}\begin{array}{l}\text { подання електронної звітності (окрім } \\
\text { формату іXBRL) }\end{array} \\
\end{array}$ & + & + & + & + & + & + & + & + \\
\hline $\begin{array}{l}\text { подання електронної звітності в фор- } \\
\text { маті іXBRL }\end{array}$ & + & + & - & - & + & - & - & - \\
\hline $\begin{array}{l}\text { подання електронної звітності до НБУ } \\
\text { в форматі XML }\end{array}$ & + & + & - & - & + & - & - & - \\
\hline обмін електронними документами & + & + & + & + & + & + & - & - \\
\hline \multicolumn{9}{|l|}{ інтеграція: } \\
\hline Lombard gold & + & + & + & + & + & + & - & - \\
\hline Pawn Shop & - & - & - & - & - & - & - & - \\
\hline Pawn Expert & - & - & - & - & - & - & - & - \\
\hline Все в одному: CUProgram & + & - & - & - & - & - & - & - \\
\hline ISpro & + & + & + & + & + & - & - & - \\
\hline $\begin{array}{l}\text { 1С:Підприємство: Бухгалтерія для Ук- } \\
\text { раїни }\end{array}$ & + & + & & + & + & + & - & - \\
\hline інтуїтивно-зрозумілий інтерфейс & + & + & + & + & + & + & + & + \\
\hline
\end{tabular}

Джерело: складено на основі опрацювання $[16,17,18,19,20,21]$

технічні - критерії, що передбачають технічну здатність програмного продукту (копіювання, зберігання, резервування, обмеженість доступу користувачів, інтеграція, підтримка різних файлових форматів тощо);

технологічні - критерії, що визначають здатність програмного продукту реалізовувати необхідну технологію бухгалтерського обліку в ломбарді відповідно до запитів користувачів (можливість налагодження форми ведення бухгалтерського обліку як системи регістрів обліку, порядку і способу реєстрації та узагальнення інформації в них 3 додержанням єдиних засад, встановлених Законом України «Про бухгалтерський облік та фінан- сову звітність в Україні», та 3 урахуванням особливостей діяльності ломбарду), можливість модифікації форм первинних документів, облікових регістрів та форм нерегламентованої (управлінської) звітності), налаштування багаторівневого аналітичного обліку тощо);

комериійний - вартісний критерій, що описує ціну придбання програмного забезпечення відповідно до комплектів їх поставки або вартість доступу до хмарного середовища відповідно до строків користування;

ергономічний - критерій, що характеризує рівень комфортності у взаємодії користувача 3 програмним про- 
дуктом і який реалізується через інтуї- тивно-зрозумілий інтерфейс (табл. 4). Таблиця 4

Вимоги до бухгалтерського програмного забезпечення ломбардів

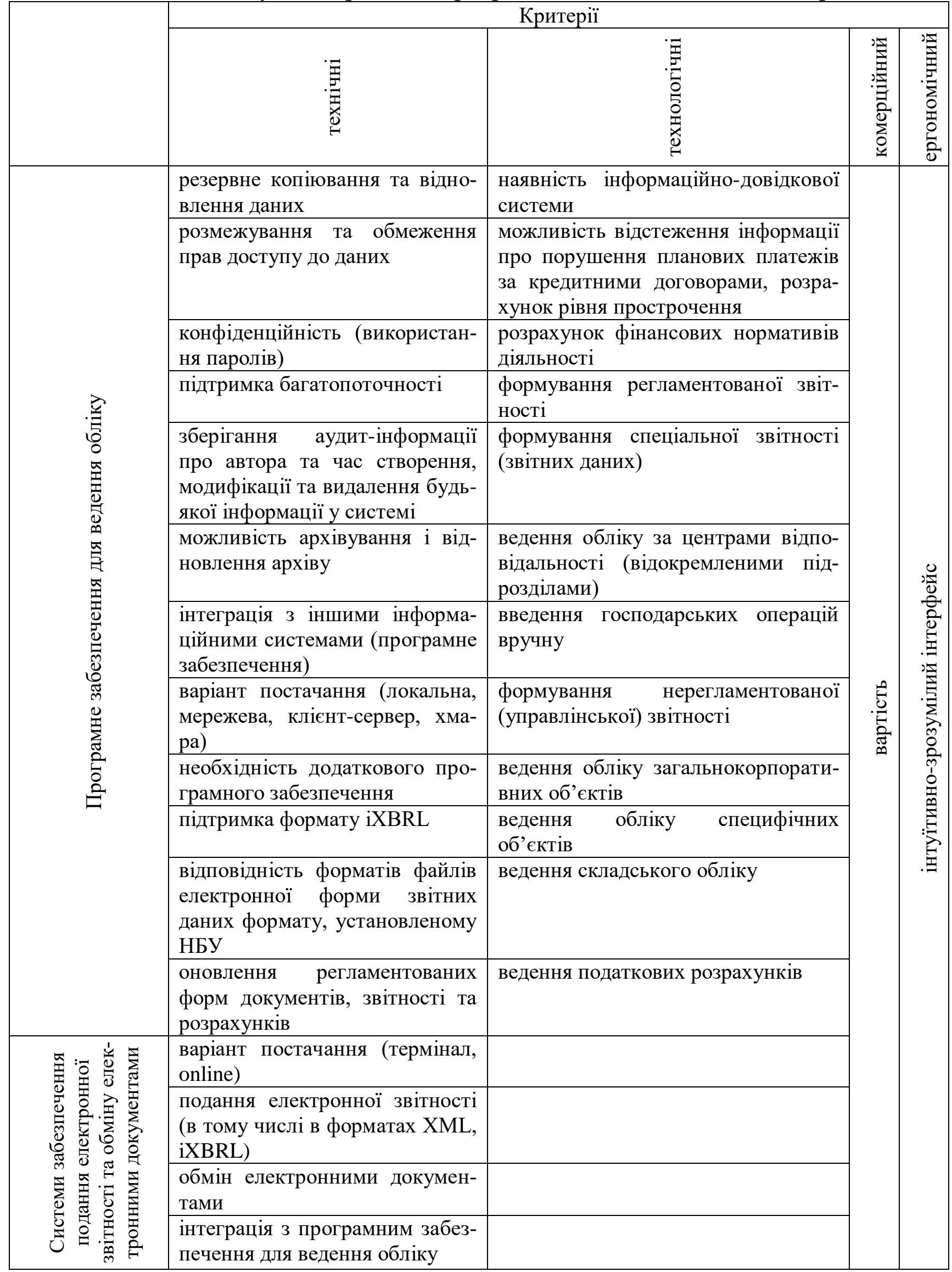

Джерело: власна розробка авторів 
Оскільки функціонування програмного забезпечення передбачає наявність певної сукупності технічних пристроїв, щодо яких також можна висувати вимоги (технічні, комерційні, ергономічні), то оптимальний вибір технічної складової організації бухгалтерського обліку буде обумовлено реципрокним характером взаємодії характеристик програмного забезпечення та технічних пристроїв.

\section{Список використаної літератури}

1. Івахненков С. В. Інформаційні технології в організації бухгалтерського обліку та аудиту: навч.посіб. К.:Знання-Прес, 2008. 347с.

2. Павелчак-Данилюк О. Обгрунтування програмного забезпечення для автоматизації бухгалтерського обліку на підприємствах. Вісник Тернопільського наиіонального технічного університету, 2014. № 1. С. 209-218. URL: http://nbuv.gov.ua/UJRN/tstub_2014_1_27. (дата звернення: 26.09.2021)

3. Чернікова І.Б., Якуба С.В. Про особливості вибору інформаційних програм бухгалтерського обліку в управлінні ринковими структурами. Економічна стратегія і перспективи розвитку сфери торгівлі та послуг, 2015. № 1. С. 4051. URL: http://nbuv.gov.ua/UJRN/esprstp_2015_1_6. (дата звернення: 26.09.2021) 4. Грибчук І.Л., Ляхович Г.I. Програмне забезпечення для ведення обліку: проблеми вибору та використання в ході аутсорсингу. Проблеми теорії та методології бухгалтерського обліку, контролю і аналізу, 2017. №. 3 (38). С. 32-36. Doi: https://doi.org/10.26642/pbo-2017-3(38)-32-36

5. Одноволик В.І. Програмне забезпечення для обліку та звітності: аналіз ринку та функціоналу. Бухгалтерський облік, аналіз та аудит: проблеми теорії, мето-

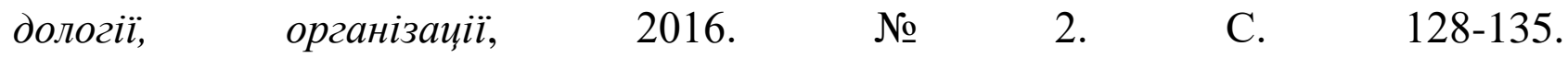
URL: http://nbuv.gov.ua/UJRN/boaa_2016_2_16_(дата звернення: 26.09.2021) 6. Гончаренко О., Лук'янець О. Розвиток організації техніки і технології ведення бухгалтерського обліку в небанківських фінансово-кредитних установах. Iнфраструктура ринку, 2019. № 30. URL: http://www.marketinfr.od.ua/journals/2019/30_2019_ukr/76.pdf (дата звернення: 26.09.2021)

7. Вольська К.О., Дикий А.П. Бухгалтерський облік у «хмарі»: порядок переходу та адаптації інформаційної системи підприємства. Проблеми теорії та методології бухгалтерського обліку, контролю і аналізу, 2017. № 2 (37). С. 24-29. DOI: http://dx.doi.org/10.26642/pbo-2017-2(37)-24-29 
8. Положення про Державний реєстр фінансових установ, затверджене розпорядженням Державної комісії з регулювання ринків фінансових послуг України від 28.08.2003 р. № 41 (у редакції розпорядження Національної комісії, що здійснює державне регулювання у сфері ринків фінансових послуг 28.11.2013 № 4368). URL: https://zakon.rada.gov.ua/laws/show/z2161-13 (дата звернення: 26.09.2021)

9. Положення про визначення умов провадження діяльності з надання фінансових послуг, здійснення яких потребує відповідної ліцензії (ліцензійних умов), затверджене постановою Правління Національного банку України № 27 від 30.03.2021 URL: https://bank.gov.ua/ua/legislation/Resolution_30032021_27_(дата звернення: 26.09.2021)

10. Положення про порядок надання фінансових послуг ломбардами, затверджене розпорядженням Державної комісії з регулювання ринків фінансових послуг України № 3981 від 26.04.2005 p. URL : https://zakon.rada.gov.ua/rada/show/z0565-05_(дата звернення: 26.09.2021)

11. Програмне забезпечення для ломбардів Lombard gold. URL: http://lombardgold.com.ua/ (дата звернення: 26.09.2021)

12. Система для управління та ведення обліку в ломбарді Pawn Shop. Pawn Expert. URL: http://da-studio.com.ua/uk/product/ (дата звернення: 26.09.2021)

13. Програмне забезпечення для фінансових установ «Все в одному: CUProgram». URL: http://www.softcu.com/ (дата звернення: 26.09.2021)

14. Програмне забезпечення для ведення обліку та управління підприємством ISpro. URL: https://ispro.ua/uk (дата звернення: 26.09.2021)

15. Огляд системи 1C: Підприємство 8. URL: http://1c.ua/ua/v8/

16. M.E.Doc. Звітність до НБУ для небанківських установ. URL: https://medoc.ua/page/zvitnist-to-nbu (дата звернення: 26.09.2021)

17. COTA. Звітність і документообіг. URL: https://sota-buh.com.ua/ (дата звернення: 26.09.2021)

18. Сервіс подання електронної звітності iFin. URL: https://www.ifin.ua/ (дата звернення: 26.09.2021)

19. COНАТА. Програма для подання електронної звітності. URL: https://sonatazvit.com.ua/ (дата звернення: 26.09.2021)

20. Програма для подання електронної звітності Арт-Звіт. Арт-Звіт URL: https://art-zvit.com.ua/instalyacii/ (дата звернення: 26.09.2021) 
21. FREDO - звітність до НБУ для небанківських установ. URL: https://fredo.com.ua/help/nbu.htm (дата звернення: 26.09.2021)

22. Постанова Правління НБУ «Про забезпечення здійснення повноважень та виконання функцій з державного регулювання та нагляду у сфері ринків фінансових послуг з питань ліцензування та реєстрації» № 83 від 25.06.2020 p. URL: https://bank.gov.ua/admin_uploads/law/25062020_83.pdf?v=4 (дата звернення: 26.09.2021) 